\title{
PENGARUH FREE CASH FLOW, KEBIJAKAN DIVIDEN, STRUKTUR AKTIVA, BLOCKHOLDER OWNERSHIP, PERTUMBUHAN PERUSAHAAN DAN UKURAN PERUSAHAAN TERHADAP KEBIJAKAN HUTANG PADA PERUSAHAAN MANUFAKTUR YANG TERDAFTAR DI BURSA EFEK INDONESIA PERIODE 2011-2015
}

\author{
Doni Hendra Saputra ${ }^{1}$ \\ (Alumni Mahasiswa Fakultas Ekonomi Universitas Maritim Raja Ali Haji) \\ Inge Lengga Sari Munthe ${ }^{2}$ (ingemunthe@yahoo.com) \\ Fakultas Ekonomi Universitas Maritim Raja Ali Haji \\ Myrna Sofia3 (bakti_2006@yahoo.co.id) \\ Fakultas Ekonomi Universitas Maritim Raja Ali Haji
}

\begin{abstract}
Penelitian ini bertujuan untuk mengetahui pengaruh free cash flow, kebijakan dividen, struktur aktiva, blockholder ownership, pertumbuhan perusahaan dan ukuran perusahaan terhadap kebijakan hutang. populasi dari objek penelitian adalah perusahaan manufaktur yang terdaftar di bei periode 2011-2015 yang berjumlah 127 perusahaan, sampel dalam penelitian berjumlah 19 perusahaan. Teknik analisis yang digunakan adalah statistik deskriptif, analisis regresi berganda, pengujian asumsi klasik, uji parsial, uji simultan dan koefesien determinasi. Hasil uji parsial menemukan bahwa variabel yang berpengaruh signifikan terhadap kebijakan hutang adalah free cash flow tingkat signifikan 0,017. Kebijakan Dividen tingkat signifikan 0,697. Struktur Aktiva tingkat signifikan 0,00. Blockholder Ownership tingkat signifikan 0,00 . Pertumbuhan Perusahaan $(0,045)$, dan Ukuran Perusahaan tingkat signifikan 0,001. Hasil uji secara simultan menemukan bahwa semua variabel independen secara simultan berpengaruh signifikan terhadap Kebijakan Hutang dengan tingkat signifikan 0,00 . Hasil koefesien determinasi menemukan hasil bahwa nilai adjusted $R$ Square adalah 0,447 atau 44,7\%. Hal tersebut dapat disimpulkan bahwa kebijakan hutang dapat dijelaskan oleh Free Cash Flow, Kebijakan Dividen, Struktur Aktiva, Blockholder Ownership, Pertumbuhan Perusahaan Dan Ukuran Perusahaan sebesar 44,7\%, sementara sisanya $55,3 \%$ dijelaskan faktor lain tidak dijelaskan dalam penelitian ini.

Kata Kunci : Free Cash Flow, Kebijakan Dividen, Struktur Aktiva, Blockholder Ownership, Pertumbuhan dan Ukuran Perusahaan, Kebijakan Hutang
\end{abstract}

\section{PENDAHULUAN}

Menurut Direktorat Jendral Pajak yang dikutip dari detik Finance 2013 menyatakan banyak perusahaan yang melakukan rekayasa utang untuk mengurangi besaran pajaknya. Salah satu cara yang digunakan yaitu memperbesar hutang sehingga bunga hutang besar dan pajaknya menurun. Dengan adanya pajak penghasilan perusahaan, hutang dapat menghemat pajak yang dibayar karena hutang menimbulkan pembayaran bunga yang mengurangi jumlah penghasilan yang terkena pajak (Atmaja, 2008:8). 
Menurut Brigham dan Houston (2011:186) Manajer sering kali menggunakan kelebihan kas untuk mendanai proyek kesayangan mereka atau untuk fasilitas seperti ruang kantor yang mewah, jet perusahaan dan kotak khusus di arena-arena olahraga, yang kesemuanya hanya memberikan manfaat yang kecil bagi harga saham. Sebaliknya, manajer dengan arus kas bebas yang terbatas akan memiliki kemampuan yang lebih kecil untuk melakukan pengeluaran sia-sia.

Besar kecilnya dividen yang dibagikan akan mempengaruhi besar kecilnya laba yang ditahan. Laba ditahan merupakan salah satu sumber dana internal perusahaan (Sudana 2011:167). Semakin besar kebutuhan dana dimasa yang akan datang, semakin besar pula bagian laba yang ditahan perusahaan, atau semakin kecil dividen yang akan dibagikan kepada pemegan saham (Sudana, 2011:170).

Perusahaan dapat menggunakan tambahan bunga untuk mengurangi pajak atas laba perusahaan yang lebih besar (Sudana, 2011:153). Aktiva tetap yang digunakan sebagai jaminan dapat mengurangi resiko kreditor apabila perusahaan tidak mampu melunasi kewajibanya maka aktiva tersebut akan diambilalih dan dijual oleh kreditor sebagai bentuk pelunasan (Steven dan Lina dalam Keni dan Dewi, 2013:767).

Menurut Sudana (2011:153) perusahaan dapat menggunakan tambahan bunga untuk mengurangi pajak atas laba perusahaan yang lebih besar. Karena aktiva mengalami peningkatan, total utang dan total modal juga akan mengalami peningkatan (Sudana, 2011:57). Ukuran perusahaan secara langsung mencerminkan tinggi rendahnya aktivitas operasi suatu perusahaan. Pada umumnya semakin besar suatu perusahaan maka akan semakin besar pula aktivitasnya (Narita, 2012:2).

\section{LANDASAN TEORI}

\section{Kebijakan Hutang}

Kebijakan hutang atau debt policy merupakan keputusan perusahaan untuk memperoleh dana dari pihak ketiga untuk melakukan investasi (Hardiningsih dan Oktaviani, 2012:12). Kebijakan hutang merupakan kebijakan yang diambil oleh pihak manajemen dalam rangka memperoleh sumber pembiayaan bagi perusahaan sehingga dapat digunakan untuk membiayai aktivitas operasional perusahaan (Syadeli, 2013:80).

\section{Free Cash Flow}

Arus kas bebas adalah arus kas yang benar-benar tersedia untuk dibayarkan kepada investor (pemegang saham dan pemilik utang) setelah perusahaan melakukan investasi dalam asset tetap, produk baru, dan modal kerja yang dibutuhkan untuk mempertahankan operasi yang sedang berjalan (Brigham dan Houston, 2013:109).

\section{Kebijakan Dividen}

Kebijakan dividen merupakan keputusan yang diambil oleh perusahaan apakah laba yang diperoleh perusahaan dibagikan kepada para pemegang saham dalam bentuk dividen atau akan ditahan dalam bentuk laba ditahan (Sheisarvian et.al, 2015:2).

\section{Struktur Aktiva}

Struktur aktiva adalah kekayaan atau sumber-sumber ekonomi yang dimiliki oleh perusahaan yang diharapkan akan memberi manfaat dimasa yang akan datang (Kesuma dalam Hidayat, 2013:16). Struktur aktiva adalah perimbangan atau perbandingan baik dalam artian 
absolut maupun dalam artian relatif antar aktiva lancar dan aktiva tetap (Riyanto dalam Hani dan Rahmi, 2014:93).

\section{Blockholder Ownership}

Menurut Gorton dan Kahl (dalam Lestari, 2014:45) Blockholder ownership merupakan salah satu struktur kepemilikan perusahaan. Blockholder merupakan shareholder yang kepemilikannya paling sedikit 5\% atas saham perusahaan Menurut Thomsen. S, et.al, (dalam Sofia, 2012:68-69) menyatakan bahwa Blockholder ownership tersebut merupakan para pemilik perusahaan yang memiliki saham lebih dari $5 \%$, saham dimiliki oleh karyawan, direktur, atau anggota keluarga yang lain, saham dimiliki oleh pihak bank, perusahaan lain (kecuali perusahaan dalam status digadaikan), saham dimiliki seseorang karena adanya tunjangan pensiun.

\section{Pertumbuhan Perusahaan}

Pertumbuhan perusahaan merupakan gambaran bagaimana perkembangan usaha yang dilakukan periode sekarang dibandingkan dengan periode sebelumnya. Suatu perusahaan yang mengalami pertumbuhan yang tinggi berarti perusahaan tersebut berhasil meningkatkan nilai perusahaan untuk menghasilkan keuntungan atau laba (Hardiningsih dan Oktaviani, 2012:16). Firm growth atau tingkat pertumbuhan perusahaan merupakan tingkat perubahan aset dari tahun ke tahun (Hendria, 2015:5).

\section{Ukuran Perusahaan}

Menurut Hendriksen dan Eldon (dalam Hasan, 2014:93) mendefinisikan size adalah ukuran perusahaan merupakan keseluruhan dari aktiva yang dimilki oleh suatu perusahaan yang dapat dilihat dari sisi kiri neraca. Jadi ukuran perusahaan (size) juga dapat diartikan sebagai keseluruhan kekayaan yang dimiliki oleh perusahaan baik dalam bentuk aktiva lancar maupun aktiva tetap.

\section{Pengembangan Hipotesis}

\section{Pengaruh Free cash flow terhadap Kebijakan Hutang}

Dari hasil penelitian Astuti dan Nurlaelasari (2013) menunjukan bahwa arus kas bebas memiliki pengaruh signifikan terhadap Kebijakan Hutang. Hasil penelitian Hasan (2014) juga mengemukakan hasil penelitian yang sama bahwa Free cash flow memiliki pengaruh terhadap kebijakan hutang. Ini menunjukan bahwa semakin besar nilai Free cash flow maka semakin tinggi nilai DER. Sementara dari penelitian Hardiningsih dan Oktaviani (2012) menunjukan hasil yang berbeda, bahwa Free cash flow tidak berpengaruh terhadap kebijakan hutang, maka dapat diambil hipotesis sebagai berikut:

$\mathrm{H}_{1}$ : Diduga Free cash flow memiliki pengaruh signifikan terhadap Kebijakan Hutang

\section{Pengaruh Kebijakan Dividen terhadap Kebijakan Hutang}

Penelitian yang dilakukan oleh Keni dan Dewi (2013) yang menunjukan bahwa kebijakan deviden berpengaruh terhadap kebijakan hutang. Semakin tinggi pembayaran deviden maka semakin tinggi perusahaan membutuhkan dana eksternal yang tak lain adalah hutang untuk membiayai kegiatan investasinya. Murtiningtyas (2012) menunjukan hasil yang berbeda, kebijakan deviden tidak berpengaruh terhadap kebijakan hutang, maka dapat diambil hipotesis sebagai berikut:

$\mathrm{H}_{2}$ : Diduga Kebijakan Deviden memiliki pengaruh signifikan terhadap Kebijakan Hutang 
Pengaruh Free Cash Flow, Kebijakan Dividen, Struktur Aktiva, Blockholder Ownership, Pertumbuhan Perusahaan Dan Ukuran Perusahaan Terhadap Kebijakan Hutang Pada Perusahaan Manufaktur Yang Terdaftar Di Bursa Efek Indonesia Periode 2011-2015

\section{Pengaruh Struktur Aktiva terhadap Kebijakan Hutang}

Penelitian yang dilakukan oleh Marhamah (2016) menunjukan bahwa struktur aktiva tidak mempunyai pengaruh terhadap kebijakan hutang. Hal ini dikarenakan perusahaan melakukan revaluasi aset, akibatnya aset tetap naik tanpa harus membeli aset tetap yang baru. Hasil penelitian yang dilakukan oleh Keni dan Dewi (2012) menunjukan hasil yang berbeda, bahwa struktur aktiva memiliki pengaruh terhadap kebijakan hutang, maka dapat diambil hipotesis sebagai berikut:

$\mathrm{H}_{3}$ : Diduga bahwa Struktur Aktiva memiliki pengaruh signifikan terhadap Kebijakan Hutang.

\section{Pengaruh Blockholder ownership terhadap Kebijakan Hutang}

Hasil penelitian yang dilakukan oleh Wiliandri (2011) menunjukan bahwa Blockholder ownership tidak memiliki pengaruh signifikan terhadap DER. Sementara penelitian yang dilakukan Lestari (2014) menunjukkan hasil berbeda bahwa Blockholder ownership (BO) terbukti berpengaruh signifikan terhadap kebijakan hutang (DEBT). Hal ini berkaitan dengan peningkatan pengawasan oleh blockholder dan menghindari financial distress, maka hipotesis yang dibuat sebagai berikut:

$\mathrm{H}_{4}$ : Diduga Blockholder ownership memiliki pengaruh signifikan terhadap Kebijakan Hutang.

\section{Pengaruh Pertumbuhan Perusahaan terhadap Kebijakan Hutang}

Penelitian yang dilakukan oleh Marhamah (2016) menunjukan bahwa pertumbuhan perusahaan tidak memiliki pengaruh terhadap kebijakan hutang, Sementara dari penelitian Hardiningsih dan Oktaviani (2012) menunjukan hasil bahwa pertumbuhan perusahaan memiliki pengaruh signifikan terhadap kebijakan hutang. maka diambil hipotesis sebagai berikut: $\mathrm{H}_{5}$ : Diduga Pertumbuhan Perusahaan memiliki pengaruh signifikan terhadap Kebijakan Hutang.

\section{Pengaruh Ukuran Perusahaan terhadap Kebijakan Hutang}

Hasil penelitian Wiliandri (2011) menunjukan hasil bahwa variabel Firm size berpengaruh terhadap DER. Namun hasil yang berbeda ditemukan oleh Keni dan Dewi (2012) yang menunjukan bahwa ukuran perusahaan tidak berpengaruh terhadap kebijakan hutang, maka diambil hipotesis sebagai berikut:

$\mathrm{H}_{6}$ : Diduga bahwa Ukuran Perusahaan memiliki pengaruh signifikan terhadap Kebijakan Hutang.

$\mathrm{H}_{7}$ : Diduga bahwa Free cash flow, Kebijakan Dividen, Struktur Aktiva, Blockholder ownership, Pertumbuhan Perusahaan dan Ukuran Perusahaan secara simultan memiliki pengaruh signifikan terhadap Kebijakan Hutang.

\section{METODE PENELITAN}

\section{Kebijakan Hutang}

Menurut Hanafi et.al, (dalam Hasan, 2014:92) kebijakan hutang diukur dengan menggunakan debt to equity ratio (DER), Formula yang digunakan untuk menghitung rasio ini adalah sebagai berikut (Prasetyo, 2011:20):

$$
\mathrm{DER}=\frac{\text { Total Hutang }}{\text { Total Ekuitas }}
$$




\section{Free Cash Flow}

Menurut Harrison, Horngren, Thomas dan Suwardy (2013:199), Formula tersebut dapat dirimuskan sebagai berikut:

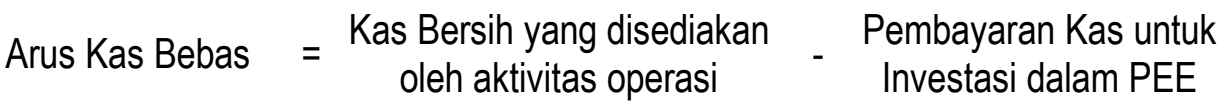

\section{Kebijakan Deviden}

Kebijakan deviden merupakan persentase keuntungan yang didapat oleh pemegang saham dalam bentuk dividen. Deviden payout ratio (DPR) dapat digambarkan sebagai berikut (Sudana, 2011:24):

$$
\mathrm{DPR}=\frac{\text { Dividen }}{\text { Earning After Tax }}
$$

\section{Struktur Aktiva}

Menurut Marhamah (2016:22) perusahaan yang mempunyai aktiva tetap lebih banyak, mampu untuk menerbitkan hutang juga lebih besar dikarenakan ada jaminan untuk menerbitkan surat hutang. Formula yang digunakan Marhamah (2016) dalam variabel struktur aktiva sebagai berikut:

$$
\text { Struktur Aktiva }=\frac{\text { Total Aset Tetap }}{\text { Total Aset }}
$$

\section{Blockholder ownership}

Thomsen S, et.al., (dalam Sofia, 2012:68-69) menjelaskan bahwa Blockholder ownership tersebut merupakan para pemilik perusahaan yang memiliki saham lebih dari $5 \%$, saham dimiliki oleh karyawan, direktur, atau anggota keluarga yang lain, saham dimiliki oleh pihak bank, perusahaan lain (kecuali perusahaan dalam status digadaikan), saham dimiliki seseorang karena adanya tunjangan pensiun. Kepemilikan blockholder menggambarkan rasio saham yang dimiliki oleh blockholder, dan dalam penelitian Lestari (2014) Blockholder ownership dapat dihitung dengan rumus sebagai berikut:

$$
\mathrm{BO}=\frac{\text { Saham yang dimiliki oleh Blockholder }}{\text { Jumlah Saham yangberedar }} \times 100 \%
$$

\section{Pertumbuhan Perusahaan}

Pertumbuhan perusahaan merupakan gambaran bagaimana perkembangan usaha yang dilakukan periode sekarang dibandingkan dengan periode sebelumnya. Suatu perusahaan yang mengalami pertumbuhan yang tinggi berarti perusahaan tersebut berhasil meningkatkan nilai perusahaan untuk menghasilkan keuntungan atau laba (Hardiningsih dan Oktaviani, 2012:16). Perhitungan pertumbuhan perusahaan menggunakan indikator penjualan dilakukan dengan rumus sebagai berikut (Prasetyo, 2011:112):

$$
\text { Pertumbuha } n \text { Perusahaan }=\frac{\text { Penjualan }_{\mathrm{t}}-\text { Penjualan }_{\mathrm{t}-1}}{\text { Penjualan }_{\mathrm{t}-1}}
$$

\section{Ukuran Perusahaan}

Menurut Hendriksen dan Eldon (dalam Hasan, 2014:93) mendefinisikan size adalah ukuran perusahaan merupakan keseluruhan dari aktiva yang dimilki oleh suatu perusahaan yang dapat 
Pengaruh Free Cash Flow, Kebijakan Dividen, Struktur Aktiva, Blockholder Ownership, Pertumbuhan Perusahaan Dan Ukuran Perusahaan Terhadap Kebijakan Hutang Pada Perusahaan Manufaktur Yang Terdaftar Di Bursa Efek Indonesia Periode 2011-2015

dilihat dari sisi kiri neraca. Jadi ukuran perusahaan (size) juga dapat diartikan sebagai keseluruhan kekayaan yang dimiliki oleh perusahaan baik dalam bentuk aktiva lancar maupun aktiva tetap. Formula yang digunakan oleh Nuraina (2012) untuk menghitung ukuran perusahaan sebagai berikut:

Ukuran Perusahaan $=$ Total Akiva

\section{Populasi dan Sampel}

Adapun daftar populasi perusahaan yang menjadi sampel dalam penelitian dan memenuhi kriteria-kriteria yang ditetapkan sebelumnya untuk mendapatkan sampel yang dibutuhkan adalah 127 perusahaan. Sedangkan perusahaan yang dapat dijadikan sampel dan sesuai dengan seluruh kriteria yang dibutuhkan dalam penelitan ini berjumlah 19 perusahaan.

\section{Analisis Regresi Berganda}

Dimana keterangan dari formula diata s adalah sebagai berikut:

$$
Y=\beta_{0}+\beta_{1} x_{1}+\beta_{2} X_{2}+\beta_{3} X_{3}+\beta_{4} X_{4}+\beta_{5} x_{5}+\beta_{6} X_{6}+e
$$

$Y=$ Kebijakan Hutang $\quad X_{3}=$ Struktur Aktiva

$\beta_{1}-\beta_{6}=$ Koefesien regresi $\quad X_{4}=$ Blockholder ownership

$X_{1}=$ Free cash flow $\quad X_{5}=$ Pertumbuhan Perusahaan

$X_{2}=$ Kebijakan Deviden $\quad X_{6}=$ Ukuran Perusahaan

\section{Uji Asumsi Klasik}

e $\quad=$ error

Berikut adalah tahap awal pemeriksaaan terhadap hasil analisis regresi linier berganda. Tahap ini merupakan pemeriksaaan dalam pemenuhan asumsi, yaitu Normalitas error (error mengikuti distribusi normal), Varians error yang konstan (error bersifat homoskedastisitas- tidak ada problem heterokedastisitas), Tidak adanya korelasi serial diantara error pengamatan (tidak ada masalah otokorelasi), Tidak ada hubungan yang sangat tinggi (multikolineritas) diantara variabel independen (Yamin, et.al, 2011:31-32)

Pengujian Secara Keseluruhan, Menurut Yamin, et.al, (2011:36) pengujian secara keseluruhan diperlukan untuk mengetahui apakah semua variabel independen berpengaruh terhadap variabel dependenya. Tingkat signifikansi 5\% $(0,05)$. Alat uji yang digunakan adalah uji $\mathrm{F}$ serta kriteria penarikan kesimpulan apabila $\mathrm{H}_{0}$ diterima jika nilai $\mathrm{p}$-value $>0,05(5 \%)$ dan sebaliknya. Pengujian Parsial Menurut Yamin, et.al, (2011:37) pengujian secara parsial dilakukan untuk mengetahui pengaruh dari masing-masing variabel independen terhadap variabel dependennya. Alat uji yang digunakan adalah uji t dengan tingkat signifikansi $5 \%(0,05)$ serta kriteria penarikan kesimpulan apabila nilai $\mathrm{p}$-value $>0,05 \mathrm{H}_{0}$ diterima dan sebaliknya.

Koefisien Determinasi (Uji $\mathrm{R}^{2}$ ), Koefisien determinasi adalah suatu ukuran yang dapat menjelaskan porsi variasi variabel terikat yang dapat dijelaskan oleh garis regresinya atau variabel bebasnya. Nilai koefisien determinasi terletak antara 0 dan 1 yaitu $0 \leq r^{2} \leq 1$. Bila $r^{2}=1$ berarti $100 \%$ total variasi varaibel terikat dijelaskan oleh variabel bebasnya dan menunjukan ketepatan yang baik. Dan bila $r^{2}=0$ berarti tidak ada total variasi variabel terikat yang dijelaskan oleh variabel bebasnya (Budiasih, 2012:198). Biasanya dalam model regresi berganda yang digunakan adalah nilai koefesien determinasi yang disesuaikan (Adjusted R2). Karena setiap tambahan satu variabel independen maka R2 pasti akan meningkat, meskipun variabel tersebut tidak signifikan (Purwanto dan Sulistyastuti, 2011:195). 


\section{HASIL PENELITIAN}

Karena data mengalami masalah tidak normal dalam uji normalitas, maka dilakukan outlier dengan nilai (ZScore). Hasil untuk statistik deskriptif juga mengalami perubahan karena jumlah observasi menjadi berkurang, hal ini dapat dilihat pada tabel berikut.

Tabel 1. Statistik Deskriptif Setelah Outlier

Descriptive Statistics

\begin{tabular}{lrrrrr}
\hline & N & Minimum & Maximum & \multicolumn{1}{c}{ Mean } & \multicolumn{1}{c}{$\begin{array}{c}\text { Std. } \\
\text { Deviation }\end{array}$} \\
\hline Blockholder Ownership & 72 & .5007 & .9818 & .784967 & .1382199 \\
\hline Free Cash Flow & 72 & -3.4583 & 3.8611 & .222348 & 1.1643012 \\
\hline Kebijakan Dividen & 72 & .0513 & 1.1821 & .400657 & .2121728 \\
\hline Kebijakan Hutang & 72 & .1082 & 1.8477 & .562731 & .3041224 \\
\hline Pertumbuhan Perusahaan & 72 & .0019 & .2917 & .126560 & .0715268 \\
\hline Struktur Aktiva & 72 & .0884 & .6448 & .293411 & .1016532 \\
\hline Ukuran Perusahaan & 72 & .2142 & 59.3242 & 9.794577 & 15.1112259 \\
\hline Valid N (listwise) & 72 & & & & \\
\hline Sumber: Output SPSS (diolah) & & & & &
\end{tabular}

Sumber: Output SPSS (diolah)

Namun untuk menghindari keselahan karena melihat bentuk visual, maka untuk menguji normalitas dapat dilakukan dengan uji Kolmogorov-Smirnov atau Shapiro wilks dengan tingkat signifikan 5\% dan uji tersebut: pertama Uji Kolmogorov-Smirnov Berdasarkan hasil uji Kolmogorov-Smirnov pada Tabel 4.3 tingkat signifikan 0,022 lebih kecil dari 0,05 $(0,022<0,05)$, namun berdasarkan tingkat signifikan dari uji Shapiro wilk lebih besar dari 0,05 atau $(0,090>$ $0,05)$ artinya Ho dapat diterima, maka dapat dikatakan error berdistribusi normal. Kedua Uji Heterokedastisitas; Langkah-langkah untuk mengetahui terjadinya heterokedastisitas pada uji white adalah dengan melihat nilai $n{ }^{*} \mathrm{R}^{2}$ dibandingkan dengan nilai Chi-Square pada tabel.

Apabila nilai $\mathrm{n}^{*} \mathrm{R}^{2}<$ nilai Chi-Square pada tabel, maka $\mathrm{H}_{0}$ diterima artinya tidak terdapat masalah heterokedastisitas. Jika $n^{*} \mathrm{R}^{2}>$ nilai Chi-Square pada tabel, maka $\mathrm{H}_{0}$ ditolak, artinya terdapat masalah heterokedastisitas. Nilai $n=72$ dan $R^{2} 0,162$ maka nilai $n{ }^{*} R^{2}=\left(72{ }^{*} 0,162=\right.$ $11,664)$. Nilai Chi-Square pada tabel dengan $d f=12$ adalah 21,026 . Karena nilai $n^{*} R^{2}<$ nilai ChiSquare pada tabel $(11,664<21.026)$ maka $H_{0}$ diterima, artinya tidak terdapat masalah heterokedastisitas. Ketiga Uji Autokorelasi melalui Uji Durbin Watson, Jika merujuk pada kriteria dalam pengujian uji Durbin Watson, maka angka durbin Watson pada model terletak diantara 4dU s/d 4-dL yaitu 4-dU $(4-1,8019=2,1988)<\mathrm{d}(2,311)<4-\mathrm{dL}(4-1,4430=2,557)$ artinya tidak ada kesimpulan.

Keempat Uji Multikolinieritas Hasil pengujian menunjukan bahwa nilai VIF pada masingmasing variabel lebih kecil dari 10 (VIF < 10), maka dapat dikatakan tidak terjadi gejala multikolinieritas. 
Pengaruh Free Cash Flow, Kebijakan Dividen, Struktur Aktiva, Blockholder Ownership, Pertumbuhan Perusahaan Dan Ukuran Perusahaan Terhadap Kebijakan Hutang Pada Perusahaan Manufaktur Yang Terdaftar Di Bursa Efek Indonesia Periode 2011-2015

\section{Uji Hipotesis}

Tabel 2. Uji Secara Keseluruhan (uji F)

\begin{tabular}{llccccc}
\multicolumn{7}{c}{ ANOVA $^{\mathrm{a}}$} \\
\hline & Model & Sum of Squares & Df & Mean Square & F & Sig. \\
\hline \multirow{3}{*}{1} & Regression & 3.244 & 6 & .541 & 10.574 & $.000^{\mathrm{b}}$ \\
\cline { 2 - 7 } & Residual & 3.323 & 65 & .051 & & \\
\cline { 2 - 7 } & Total & 6.567 & 71 & & & \\
\hline
\end{tabular}

a. Dependent Variable: Kebijakan Hutang

b. Predictors: (Constant), Ukuran Perusahaan, Free Cash Flow, Pertumbuhan Perusahaan, Struktur Aktiva, Kebijakan Dividen, Blockholder Ownership

Oleh karena nilai signifikan lebih kecil dari 0,05 maka Ho ditolak, hal ini menunjukan bahwa seluruh variabel independen (Free Cash Flow, Kebijakan Dividen, Struktur Aktiva, Blockholder Ownership, Pertumbuhan Perusahaan, dan Ukuran Perusahaan) secara bersama-sama memiliki pengaruh signifikan terhadap variabel dependen (Kebijakan Hutang).

Tabel 3 Uji Parsial (Uji t)

\section{Coefficients $^{a}$}

\begin{tabular}{|c|c|c|c|c|c|}
\hline \multirow[b]{2}{*}{ Model } & \multicolumn{2}{|c|}{$\begin{array}{l}\text { Unstandardized } \\
\text { Coefficients }\end{array}$} & \multirow{2}{*}{$\begin{array}{c}\text { Standardized } \\
\text { Coefficients } \\
\text { Beta }\end{array}$} & \multirow[b]{2}{*}{$t$} & \multirow[b]{2}{*}{ Sig. } \\
\hline & B & $\begin{array}{l}\text { Std. } \\
\text { Error }\end{array}$ & & & \\
\hline (Constant) & -.783 & .221 & & -3.550 & .001 \\
\hline Free Cash Flow & .061 & .025 & .232 & 2.439 & .017 \\
\hline Kebijakan Dividen & -.054 & .137 & -.037 & -.391 & .697 \\
\hline Struktur Aktiva & 1.904 & .283 & .637 & 6.736 & .000 \\
\hline Blockholder Ownership & .800 & .216 & .363 & 3.695 & .000 \\
\hline Pertumbuhan Perusahaan & .777 & .381 & .183 & 2.041 & .045 \\
\hline Ukuran Perusahaan & .007 & .002 & .351 & 3.544 & .001 \\
\hline
\end{tabular}

a. Dependent Variable: Kebijakan Hutang

Sumber: Output SPSS (diolah)

Berdasarkan hasil yang diperoleh dalam uji t dapat dijelaskan bahwa hanya variabel kebijakan dividen yang tidak berpengaruh karena nilai signifikan lebih besar dari $5 \%$ sedangkan variabel lainnya berpengaruh signifikan terhadap kebijakan hutang.

Tabel 4 Koefesien Determinasi

Model Summaryb

\begin{tabular}{lccccc}
\hline Model & $\mathbf{R}$ & $\mathbf{R}$ Square & $\begin{array}{c}\text { Adjusted R } \\
\text { Square }\end{array}$ & $\begin{array}{c}\text { Std. Error of } \\
\text { the Estimate }\end{array}$ & Durbin-Watson \\
\hline 1 & .703a & .494 & .447 & .2261099 & 2.311 \\
\hline a. & Predictors: (Constant), Ukuran Perusahaan, Free Cash Flow, Pertumbuhan \\
\multicolumn{3}{c}{ Perusahaan, Struktur Aktiva, Kebijakan Dividen, Blockholder Ownership } \\
\hline b. & Dependent Variable: Kebijakan Hutang & Sumber :Output SPSS (diolah)
\end{tabular}


Nilai adjusted $R$ square sebesar $44,7 \%$, hasil tersebut dapat disimpulkan bahwa Kebijakan Hutang dapat dijelaskan oleh Free Cash Flow, Kebijakan Dividen, Struktur Aktiva, Blockholder Ownership, Pertumbuhan Perusahaan, dan Ukuran Perusahaan sebesar $44,7 \%$, sedangkan sisanya $55,3 \%$ dijelaskan oleh faktor-faktor lain yang tidak dibahas didalam penelitian ini.

\section{Analisis Regresi Berganda}

Berdasarkan hasil cofficients maka dapat disusun persamaan regresi berganda sebagai berikut:

$$
\begin{aligned}
& Y=-0,783+0,061 X_{1}-0,054 X_{2}+1,904 X_{3}+0,800 X_{4}+0,777 X_{4}+0,007 X_{6}+e \\
& \mathrm{Y}=\text { Kebijakan Hutang } \quad \mathrm{X}_{4}=\text { Blockholder ownership } \\
& \beta_{1}-\beta_{6}=\text { Koefesien regresi } \quad X_{5}=\text { Pertumbuhan Perusahaan } \\
& X_{1}=\text { Free cash flow } \quad X_{6}=\text { Ukuran Perusahaan } \\
& X_{2}=\text { Kebijakan Deviden } \quad \text { e }=\text { error }
\end{aligned}
$$

$X_{3}=$ Struktur Aktiva

\section{Pembahasan}

\section{Pengaruh Free cash flow terhadap Kebijakan Hutang}

Hasil penelitian ini mendukung hasil penelitian yang dilakukan oleh Astuti dan Nurlaelasari (2013) yang menunjukan bahwa arus kas bebas memiliki pengaruh signifikan terhadap Kebijakan Hutang. Sementara hasil penelitian ini tidak mendukung dari hasil penelitian Hardiningsih dan Oktaviani (2012) dan Narita (2012) yang menunjukan hasil bahwa Free cash flow tidak berpengaruh terhadap kebijakan hutang.

\section{Pengaruh Kebijakan Dividen terhadap Kebijakan Hutang}

Hasil penelitian ini tidak mendukung hasil penelitian yang dilakukan oleh Larasati (2011) dan tidak mendukung hasil penelitian yang dilakukan oleh Keni dan Dewi (2013), serta Marhamah (2016) Sementara hasil penelitian ini mendukung dari hasil penelitian yang dilakukan oleh Murtiningtyas (2012) yang menunjukan hasil bahwa kebijakan deviden tidak berpengaruh terhadap kebijakan hutang.

\section{Pengaruh Struktur Aktiva terhadap Kebijakan Hutang}

Hasil penelitian ini mendukung dari hasil penelitian yang dilakukan oleh Keni dan Dewi (2012) serta penelitian yang dilakukan oleh Hardiningsih dan Oktaviani (2012) yang menunjukan hasil bahwa struktur aktiva berpengaruh signifikan terhadap kebijakan hutang. Sementara hasil penelitian ini tidak mendukung dari hasil penelitian yang dilakukan oleh Marhamah (2016) yang menunjukan bahwa struktur aktiva tidak berpengaruh terhadap kebijakan hutang.

\section{Pengaruh Blockholder ownership terhadap Kebijakan Hutang}

Hasil penelitian ini tidak mendukung hasil penelitian yang dilakukan oleh Wiliandri (2011) yang menunjukan bahwa Blockholder ownership tidak memiliki pengaruh signifikan terhadap DER. Sementara penelitian ini mendukung hasil penelitian yang dilakukan oleh Lestari (2014) yang menunjukkan hasil bahwa Blockholder ownership (BO) terbukti berpengaruh signifikan terhadap kebijakan hutang (DEBT), dan mendukung hasil penelitian yang dilakukan oleh Maryasih dan Gemala (2014), 
Pengaruh Free Cash Flow, Kebijakan Dividen, Struktur Aktiva, Blockholder Ownership, Pertumbuhan Perusahaan Dan Ukuran Perusahaan Terhadap Kebijakan Hutang Pada Perusahaan Manufaktur Yang Terdaftar Di Bursa Efek Indonesia Periode 2011-2015

\section{Pengaruh Pertumbuhan Perusahaan terhadap Kebijakan Hutang}

Hasil penelitian ini tidak mendukung dari hasil penelitian yang dilakukan oleh Marhamah (2016) yang menunjukan bahwa pertumbuhan perusahaan tidak berpengaruh terhadap kebijakan hutang, hasil penelitian ini mendukung dari hasil penelitian yang dilakukan oleh Keni dan Dewi (2012), yang menunjukan bahwa pertumbuhan perusahaan memiliki pengaruh terhadap kebijakan hutang.

\section{Pengaruh Ukuran Perusahaan terhadap Kebijakan Hutang}

Hasil penelitian ini tidak mendukung dari penelitian yang diilakukan oleh Keni dan Dewi (2012) yang menunjukan bahwa ukuran perusahaan tidak berpengaruh terhadap kebijakan hutang. Hasil penelitian ini mendukung dari hasil penelitian yang dilakukan oleh Hasan (2014), bahwa ukuran perusahaan berpengaruh signifikan terhadap kebijakan hutang. Sementara hasil penelitian ini juga mendukung dari hasil penelitian yang dilakukan oleh Wiliandri (2011) menunjukan bahwa variabel Firm size berpengaruh terhadap DER, serta mendukung hasil penelitian yang dilakukan oleh Marhamah (2016) yang menunjukan bahwa ukuran perusahaan berpengaruh signifikan terhadap kebijakan hutang.

\section{KESIMPULAN DAN SARAN}

\section{Kesimpulan}

Adapun kesimpulan yang dapat dijelaskan sesuai dengan hasil pembahasan adalah bahwa dalam uji parsial hanya variabel kebijakan dividen yang tidak berpengaruh terhadap kebijakan hutang. Sedangkan sisanya berpengaruh signifikan terhadap kebijakan hutang. Untuk uji simultan hasilnya adalah seluruh variabel independen secara simultan berpengaruh

\section{Saran}

Berdasarkan kesimpulan yang telah dibuat, maka penulis dapat memberikan saran sebagai berikut:

1. Bagi manajer perusahaan, sebaiknya dapat memperhatikan faktor-faktor yang dapat mempengaruhi hutang karena variabel-variabel tersebut memiliki pengaruh yang signifikan terhadap keuangan perusahaan khususnya dalam penggunaan hutang didalam perusahaan. Semakin tinggi hutang yang digunakan dalam perusahaan, maka semakin besar resiko yang harus ditanggung oleh perusahaan. Oleh sebab itu, manajer dirasa perlu untuk dapat melihat serta menjaga agar perusahaan dapat beroperasi dengan normal.

2. Bagi investor, sebaiknya memperhatikan dan menganalisis terlebih dahulu keuangan perusahaan sebelum melakukan investasi pada sebuah perusahaan, karena investasi yang baik bagi investor adalah investasi yang dapat memberikan keuntungan bagi investor.. Oleh sebab itu, investor juga sebaiknya dapat memahami kondisi keuangan perusahaan dimasa depan sebelum melakukan investasi.

3. Bagi penelitian selanjutnya, mungkin dapat menambah variabel lain yang dapat mempengaruhi kebijakan hutang secara signifikan, karena masih ada sekitar $54 \%$ faktor lain yang bisa mempengaruhi kebijakan hutang perusahaan serta menambah periode penelitian agar hasil yang diperoleh jauh lebih baik lagi 


\section{DAFTAR PUSTAKA}

Astuti, Wati Aris, dan Nurlaelasari (2013), Pengaruh Arus Kas Bebas terhadap Kebijakan Utang. Trinomika (Universitas Komputer Indonesia) Vol.12 Juni, p. 40-48.

Atmaja, Lukas Setia (2008), Teori \& Praktik Manajemen Keuangan. Jakarta: ANDI.

Bank Indonesia dan Kementerian Keuangan, 2017. Statistik Utang Luar Negeri Indonesia Vol VIII. Jakarta: Bank Indonesia dan Kementerian Keuangan.

Brigham, Eugene F, and Joel F Houston, 2013. Dasar-Dasar Manajemen Keuangan. Edisi 11. Jakarta: Salemba Empat.

(2011), Dasar-dasar manajemen keuangan: essentials of financial management. Edisi 11 Buku 2. Jakarta: Salemba Empat.

Budiasih, Yanti (2012), Statistika Deskriftif untuk Ekonomi dan Bisnis. Edisi Pertama. Tanggerang: Jelajah Nusa.

Ekadjaja, Agustin, and Samuel Leonard (2009), Analisis pengaruh Free cash flow dan Persentase Kepemilikan Manajerial terhadap kebijakan Hutang pada kelompok perusahaan yang tergolong dalam LQ.45 di Bursa Efek Jakarta (Periode 2006-2007.". Jurnal Akuntansi (Fakultas Ekonomi Universitas Tarumanegara) Vol.9, No.1 Januari, p. 21-40.

Hani, Syafrida, and Dilla Ainur Rahmi, (2014), Analisis Pertumbuhan Penjualan dan Struktur Aktiva terhadap Struktur Pendanaan Eksternal. Jurnal Manajemen dan Bisnis (Fakultas Ekonomi Universitas Muhammadiyah) Vol.14, No.1 April, p. 89-97.

Hardiningsih, Pancawati, and Rachmawati Meita Oktaviani (2012), Determinan Kebijakan Hutang (Dalam Agency Theory dan Pecking Order Theory). Dinamika Akuntansi, Keuangan dan Perbankan (Program Studi Akuntansi Universitas Stikubank) Vol.1, No.1 Mei, p. 11-24.

Harrison, Walter T, Charles T Horngren, Charles William Thomas, and Themin Suwardy, 2013. Akuntansi Keuangan : International Financial Reporting Standards. kedelapan. Jakarta : Erlangga.

Hasan, Mudrika Alamsyah (2014), Pengaruh Kepemilikan Manajerial, Free cash flow, dan Ukuran Perusahaan terhadap kebijakan Utang (Studi pada perusahaan-perusahaan Industri dasar dan kimia yang terdaftar di BEI)". Jurnal Akuntansi (Fakultas Ekonomi Universitas Riau) Vol.3, No.1 Oktober p. 90-100.

Hendria, Reji (2015), Pengaruh Insider Ownership, Firm Size, Firm Growth, dan Business Risk terhadap Kebijakan Hutang perusahaan Perbankan Go Publik di Bursa Efek Indonesia". JOM FEKON (Fakultas Ekonomi Universitas Riau) Vol.2, No.1 Februari, p. 1- 15.

Hidayat, M Syafiudin (2013), Pengaruh Kepemilikan Manajerial, Kebijakan Dividen, Struktur Aktiva, Pertumbuhan Penjualan dan Ukuran Perusahaan terhadap Kebijakan Hutang." Jurnal IImu Manajemen (Fakultas Ekonomi Universitas Negeri Surabaya) Vol.1,No.1 Januari, p. 12-25.

Keni, and Sofia Prima Dewi (2013), Pengaruh Kepemilikan Institusional,Pertumbuhan Perusahaan, Struktur Aktiva, Ukuran Perusahaan, Earning Volatility dan Kebijakan Dividen terhadap Kebijakan Hutang. Jurnal Akuntansi Fakultas Ekonomi Universitas Tarumanegara) Vol.13, No.1 April, p. 761-786.

Larasati, Eva (2011), Pengaruh Kepemilikan Manajerial, Kepemilikan Institusional dan Kebijakan Dividen terhadap Kebijakan Hutang perusahaan. Jurnal Ekonomi Bisnis (Fakultas Ekonomi Universitas Tadulako), No.2 Juli, p. 103-107.

Lestari, Desi (2014), Pengaruh Blockholder Ownership, Ukuran perusahaan, Resiko Bisnis dan Nondebt tax shield terhadapa kebijakan Hutang perusahaan yang masuk di Jakarta Islamic Index. EKBISI (Fakultas Syariah dan Hukum UIN Sunan Kalijaga) Vol.IX, No.1 Desember, p. 43-58. 
Pengaruh Free Cash Flow, Kebijakan Dividen, Struktur Aktiva, Blockholder Ownership, Pertumbuhan Perusahaan Dan Ukuran Perusahaan Terhadap Kebijakan Hutang Pada Perusahaan Manufaktur Yang Terdaftar Di Bursa Efek Indonesia Periode 2011-2015

Marhamah (2016), Pengaruh Kepemilikan Manajerial, Kepemilikan Institusional, KebijakaDividen, Pertumbuhan (Growth), Ukuran Perusahaan, dan Struktur Aktiva terhadap Kebijakan Hutang perusahaan yang terdaftar di BEI". Jurnal STIE Semarang (STIE Semarang) Vol.8, No.1 Februari, p.19-35.

Maryasih, Lilis, and M Zaki Gemala (2014), Analisis pengaruh Blockholder Ownership dan Asset Tangibility terhadap Kebijakan hutang pada perusahaan Telekomunikasi yang terdaftar di BEl periode 2008-2011. Jurnal Dinamika Akuntansi dan Bisnis Universitas Syiah Kuala Vol.1, No.1 Maret, p. 72-80.

Narita, Rona Mersi (2012), Analisis Kebijakan Hutang". Accounting Analysis Journal (Fakultas Ekonomi Universitas Negeri Semarang) Vol.1, No.2 November, p. 1-6.

Nuraina, Elva (2012), Pengaruh Kepemilikan Institusional dan Ukuran Perusahaan terhadap Kebijakan Hutang dan Nilai Perusahaan (Studi pada perusahaan manufaktur yang terdaftar di BEI)". Jurnal Bisnis dan Ekonomi (JBE) IKIP PGRI (Madiun) Vol. 19 September, p. $110-125$

Prasetyo, Aries Heru (2011), Valuasi Perusahaan. Jakarta: PPM.

Purwanto, Erwan Agus, and Dyah Ratih, Sulistyastuti (2011), Metode Penelitian Kuantitatif untuk Administrasi Publik dan Masalah-Masalah Sosial. Yogyakarta: Gava Media.

Sheisarvian, Revi Maretta, Nengah Sudjana, and Muhammad Saifi, 2015. "Pengaruh Kepemilikan Manajerial, Kebijakan Dividen dan Profitabilitas terhadap Kebijakan Hutang (Studi pada perusahaan Manufaktur yang tercatat di BEI Periode 2010-2012). Jurnal Administrasi Bisnis (JAB) (Fakultas IImu Administrasi Universitas Brawijaya) Vol.22, No.1 Mei, p. 1-9.

Sofia, Myrna (2012), Pengaruh Nilai perusahaan terhadap Blockholder Ownership pada perusahaan Manufaktur yang terdaftar di Bursa Efek Indonesia. JEMI (Universitas Maritim Raja Ali Haji) Vol.3, no.1 (Juni, p. 67-76).

Sriyunianti, Fera (2013), Aliran Kas Bebas dan Kebijakan Hutang terhadapKeputusan Investasi. Jurnal Akuntansi \& Manajemen (Jurusan Akuntansi Politeknik Negri Padang) Vol.8, No.2 Desember, p. 77-87.

Sudana, I Made (2011), Manajemen Keuangan Perusahaan : Teori dan Praktek. Jakarta: Erlangga.

Suryani, Ade Dwi, and Muhammad Khafid (2015), Pengaruh Free cash flow, Pertumbuhan Perusahaan, Kebijakan Dividen dan Ukuran Perusahaan terhadap Kebijakan Hutang pada perusahaan Manufaktur di Bursa Efek Indonesia tahun 2013". Dinamika Akuntansi, Keuangan dan Perbankan (Fakultas Ekonomi Universitas Negri Semarang) Vol.4, No.1 Mei, p. 20-28.

Syadeli, Moh (2013), Struktur kepemilikan, Profitabilitas dan Ukuran Perusahaan terhadap Kebijakan Hutang perusahaan Manufaktur di Bursa Efek Indonesia. Jurnal Manajemen dan Akuntansi (STIE Malangkucucwara) Vol.2, No.2 Agustus, p. 79-94.

W., Soeparno (2009), Analisis Forecasting Dan Keputusan Manajemen. Jakarta: Salemba Empat.

Wiliandri, Ruly (2011), Pengaruh Blockholder ownership dan Firm Size terhadap Kebijakan Hutang perusahaan. Jurnal Ekonomi dan Bisnis (Fakultas Ekonomi Universitas Negeri Semarang) Th.16, No.2 Juli, p. 95-102.

Yamin, Sofyan, Lien Auliya Rachmach, and Heri Kurniawan, 2011. Regresi dan Korelasi dalam Genggaman Anda; Aplikasi dengan Software SPSS, EViews, Minitab dan Stagraphics. Jakarta: Salemba Empat. 